\title{
Antioxidant enzyme levels in intestinal and renal tissues after a 60 -minute exercise in untrained mice
}

\author{
I. Semin, O. Acikgöz, S. Gönenc, N. Uysal, \\ B. M. Kayatekin
}

Department of Physiology, Dokuz Eylül University Medical School, Izmir, Turkey

Received: January 5, 2001

Accepted: March 1, 2001

\begin{abstract}
The present study was designed to determine the effects of exercise on the antioxidant enzymatic system and lipid peroxidation in small intestine and kidney, during the post-exercise period in untrained mice. Two days after the last adaptation running exercise, animals were ran on the treadmill for $60 \mathrm{~min}$ at $18 \mathrm{~m} / \mathrm{min}, 5$ degrees slope. After the acute exercise the animals were killed by cervical dislocation, immediately $(0 \mathrm{~h}), 3$ hours $(3 \mathrm{~h})$ and 24 hours $(24 \mathrm{~h})$ after the exercise. Control animals were killed without running exercise. Their proximal small intestinal and renal tissues were quickly removed. Changes in the concentration of thiobarbituric acid reactive substance (TBARS), as an index of lipid peroxidation, in intestine and kidney were studied in mice after the running exercise and in unexercised control group. The activities of superoxide dismutase (SOD) and glutathione peroxidase (GPx) were determined in these tissues. Tissue SOD, GPx activities and TBARS level were not increase by the exercise in kidney. Intestinal SOD activity decreased after exercise $(0 \mathrm{~h}$ and $3 \mathrm{~h}$ respectively, $\mathrm{p}<0.05, \mathrm{p}<0.01)$ and returned to control levels. Intestinal GPx activity increased after exercise $(0 \mathrm{~h}, \mathrm{p}<0.05)$ and returned to control levels. There was no significant difference among groups in intestinal tissue TBARS levels. These findings could suggest that submaximal exercise may not cause oxidative stress in proximal small intestinal tissue and kidney.
\end{abstract}

Keywords: exercise, mice, glutathione peroxidase, superoxide dismutase, thiobarbituric acid reactive substance

Correspondence should be addressed to

Berkant Muammer Kayatekin, MD

Dokuz Eylül University Medical School

Department of Physiology

35340 Balçova, Ýzmir, Turkey

Fax: 00-90-232-2590541

E-mail: kayabm@deu.edu.tr 
During strenuous exercise there is a dramatic increase in oxygen uptake in various organs. Oxygen-centered radicals are produced in intermediate metabolism (1). Most of the oxygen consumed in the mitochondria is utilized to produce adenosine 5'triphosphate, but during oxidative phosphorylation the superoxide radicals, hydrogen peroxide, and hydroxy radicals are produced by the univalent reduction of oxygen and leak out of the electron transfer chain (5). As a whole, they are classified as reactive oxygen species (ROS) and are responsible for a series of biochemical and physiological changes, namely oxidative stress. In the resting state the body is equipped with both non-enzymatic and enzymatic antioxidant reserves to prevent the potentially harmful effects of ROS (14). Primary components of the physiological antioxidant defence are superoxide dismutase (SOD), catalase and glutathione peroxidase (GPx). SOD catalyzes the dismutation of superoxide to $\mathrm{O}_{2}$ and $\mathrm{H}_{2} \mathrm{O}_{2}$. GPx can reduce $\mathrm{H}_{2} \mathrm{O}_{2}$ to form glutathione disulfide and water (28). The fine physiological balance between oxidative reactions and antioxidant capacity may be perturbed by intense physical activity. The ROS released cause the lipid peroxidation of polyunsaturated fatty acids in the biological membranes and blood, inducing alterations of the cell functions (9). Strenuous physical exercise induces oxidative damage to lipids in various tissues (28). Free radical mediated events are believed to be involved in ischemia-reperfusion injury in skeletal muscle, heart, kidney, pancreas, small intestine, brain, and skin $(16,17)$.

Increased energy demand during physical exercise, especially of the aerobic type, necessitates a multifold increase in oxygen supply to active tissues. The rate of oxygen uptake by the body during exercise may increase by 10 to 15 fold (28). During exercise, there are great blood perfusion disturbances among tissues. Skeletal muscle perfusion is increased, while splanchnic area perfusion is decreased and then they return to normal levels $(7,19)$. In other words, ischemia/reperfusion occurs in splanchnic area.

Gastrointestinal disturbances like pain, diarrhea, melena $(3,10,20,31)$ and hematuria $(6,15,29)$ are reported in sportsmen, especially $1-2$ days after a marathon. Running-induced bleeding may be due to transient gut ischemia, because during vigorous exercise splanchnic perfusion decreases by as much as $80 \%$ (7). Furthermore, diarrhea and other abdominal complaints common during or after long-distance running have been attributed to splanchnic ischemia $(3,10)$.

The present study was designed to determine the effects of exercise on the antioxidant enzymatic system and lipid peroxidation in small intestine and kidney, during the post-exercise period in untrained mice. 


\section{Materials and Methods}

\section{Chemicals}

RANSOD and RANSEL kits were obtained from Randox labs., Crumlin, UK. The rest of chemicals were purchased from Sigma Chemical Co., St. Louis, MO, USA.

Animals

Male Swiss Albino mice ( $\mathrm{n}=20)$, weighing 29.5 $\pm 1.5 \mathrm{~g}$, were used. Animals were housed in a temperature-controlled room $\left(20 \pm 2{ }^{\circ} \mathrm{C}\right)$ with a $12 \mathrm{~h}$ light-dark cycle, and were allowed free access to standard rat chow and water.

\section{Exercise programme}

Training and running exercises were performed on four small animal treadmills. All procedures were carried out between $9^{00}$ and $12^{00}$ a.m. 20 mice were randomly assigned to one of four groups; unexercised control $(n=5)$, cervical dislocation immediately after exercise $(0 \mathrm{~h}, \mathrm{n}=5), 3$ hours after exercise $(3 \mathrm{~h}, \mathrm{n}=5)$, and 24 hours after exercise $(24 \mathrm{~h}, \mathrm{n}=5$ ). Mice were ran for $18 \mathrm{~m} / \mathrm{min}, 5$ degrees slope, $5 \mathrm{~min} / \mathrm{session}$, 5 daily sessions/week for a week to adapt running.

\section{Tissue sampling}

Two days after the last adaptation of running, animals were ran on the treadmill for $60 \mathrm{~min}$ at $18 \mathrm{~m} / \mathrm{min}, 5$ degrees slope (32). The animals were killed by dislocation, immediately $(0 \mathrm{~h}), 3$ hours $(3 \mathrm{~h})$ and 24 hours $(24 \mathrm{~h})$ after the exercise. Control animals were killed without running exercise. Their proximal small intestinal and renal tissues were quickly removed. Tissues were washed in cold homogenate medium and visible clots removed to minimise blood contamination. Tissues' homogenates were prepared as described by Carrillo et al. (4). An aliquot of the homogenate and supernatant was stored at $-70{ }^{\circ} \mathrm{C}$ until the determination of TBARS levels and enzyme activities.

Determination of SOD activity

SOD activity was determined using a Randox test combination (RANSOD). Xanthine and xanthine oxidase were used to generate superoxide radicals that react with 2-4-iodophenyl-3-4-nitrophenol-5 phenyl tetrazolium chloride (INT) to form a red formazan dye. Concentration substrates were $0.075 \mu \mathrm{mol}$ for xanthine and $0.037 \mu \mathrm{mol}$ 
for INT. SOD inhibits this reaction by converting the superoxide radical to oxygen. A SOD unit inhibits the rate of reduction of INT by $50 \%$ in a complex system with xanthine and xanthine oxidase. Due to small linearity range of the test, the sample must be diluted so that the percentage of inhibition falls between $30 \%$ and $60 \%$. A standard curve was prepared using the standard provided in the kit, and the value for the supernatant was read from this curve. SOD activity was measured at $505 \mathrm{~nm}$ on a Shimadzu UV-1201V spectrometer in the supernatant. Results were expressed as SOD $\mathrm{U} / \mathrm{mg}$ protein.

\section{Determination of GPx activity}

GPx was determined using a Randox test combination (RANSEL). GPx catalyses the oxidation of glutathione (at a concentration of $5 \mu \mathrm{mol}$ ) by cumene hydroperoxyde according to method of Paglia et al. (23). In the presence of glutathione reductase (at a concentration $\geq 0.75 .10^{-3} \mathrm{U}$ ) and $0.35 \mu \mathrm{mol}$ of $\mathrm{NADPH}$, the oxidized glutathione is immediately converted to reduced form with a concomitant oxidation of NADPH to $\mathrm{NAD}^{+}$. The decrease in absorbance at $340 \mathrm{~nm}$ was measured at $37^{\circ} \mathrm{C}$. The assay was performed on a supernatant. The GPx unit was defined as the enzyme activity necessary to convert $1 \mu \mathrm{mol}$ of NADPH to NADP in $1 \mathrm{~min}$. Results were expressed as GPx U/mg protein.

\section{Determination of TBARS level}

TBARS level was estimated according to the method of Rehncrona et al. (26). $0.5 \mathrm{ml}$ of homogenates were extracted with $0.5 \mathrm{ml}$ of trichloroacetic acid $(20 \% \mathrm{wt} / \mathrm{vol})$. After centrifugation, $0.9 \mathrm{ml}$ of supernatant was added to $1 \mathrm{ml}$ of thiobarbituric acid $(0.67 \% \mathrm{wt} / \mathrm{vol})$. The samples were heated in boiling water for $10 \mathrm{~min}$. After cooling the absorbance was recorded at $532 \mathrm{~nm}$. A standard curve was prepared using 1, 1, 3, 3tetraethoxypropane and the value for the homogenate was read from this curve. The results were expressed as nmol/mg protein.

\section{Determination of protein concentration}

Protein contents of supernatant and homogenate were determined using the modification proposed by Markwell et al. (18) of the method of Lowry using bovine serum albumin as a standard. 


\section{Statistical analysis}

Results are presented as means \pm S.D. Statistical analysis of the data was performed using Mann-Whitney U test.

\section{Results}

Tissue SOD, GPx activities and TBARS level were unaffected by the exercise in the kidney. Tissue SOD, GPx activities and TBARS levels in the kidney were shown in Table I.

Table I

The effects of exercise on tissue SOD, GPx activities and TBARS levels in kidney

\begin{tabular}{lccc}
\hline Groups & $\begin{array}{c}\text { SOD } \\
(\mathrm{U} / \mathrm{mg} \text { protein })\end{array}$ & $\begin{array}{c}\text { GPx } \\
(\mathrm{U} / \mathrm{mg} \text { protein })\end{array}$ & $\begin{array}{c}\text { TBARS } \\
(\text { nmol/mg protein })\end{array}$ \\
\hline Control & $5.47 \pm 1.59$ & $0.58 \pm 0.31$ & $0.05 \pm 0.02$ \\
$0 \mathrm{~h}$ & $5.08 \pm 0.62$ & $0.43 \pm 0.15$ & $0.05 \pm 0.01$ \\
$3 \mathrm{~h}$ & $4.84 \pm 0.86$ & $0.43 \pm 0.08$ & $0.05 \pm 0.01$ \\
$24 \mathrm{~h}$ & $4.51 \pm 1.09$ & $0.48 \pm 0.10$ & $0.04 \pm 0.01$ \\
\hline
\end{tabular}

The values presented as means \pm S.D. of five animals per group.

The animals were killed by dislocation, immediately $(0 \mathrm{~h}), 3$ hours $(3 \mathrm{~h})$ and 24 hours $(24 \mathrm{~h})$ after the exercise. Control animals were killed without running exercise.

Table II

The effects of exercise on tissue SOD, GPx activities and TBARS levels in small intestine

\begin{tabular}{lccc}
\hline Groups & $\begin{array}{c}\text { SOD } \\
(\text { U/mg protein })\end{array}$ & $\begin{array}{c}\text { GPx } \\
(\text { U/mg protein })\end{array}$ & $\begin{array}{c}\text { TBARS } \\
\text { (nmol/mg protein) }\end{array}$ \\
\hline Control & $2.47 \pm 0.23$ & $0.04 \pm 0.02$ & $0.25 \pm 0.04$ \\
$0 \mathrm{~h}$ & $2.12 \pm 0.24^{*}$ & $0.09 \pm 0.01^{* * *}$ & $0.22 \pm 0.03$ \\
$3 \mathrm{~h}$ & $1.79 \pm 0.43^{* *}$ & $0.06 \pm 0.03$ & $0.28 \pm 0.07$ \\
$24 \mathrm{~h}$ & $2.19 \pm 0.59$ & $0.07 \pm 0.03$ & $0.24 \pm 0.03$ \\
\hline
\end{tabular}

The values presented as means \pm S.D. of five animals per group.

The animals were killed by dislocation, immediately $(0 \mathrm{~h}), 3$ hours $(3 \mathrm{~h})$ and 24 hours $(24 \mathrm{~h})$ after the exercise. Control animals were killed without running exercise.

* Lower than control $\mathrm{p}<0.05$

** Lower than control $\mathrm{p}<0.01$

*** Higher than control $\mathrm{p}<0.05$ 
Intestinal SOD activity decreased after exercise (respectively, $0 \mathrm{~h}$ and $3 \mathrm{~h}$, $\mathrm{p}<0.05, \mathrm{p}<0.01)$ and returned to control levels. Intestinal GPx activity increased after exercise $(0 \mathrm{~h}, \mathrm{p}<0.05)$ and returned to control levels. There was no significant difference among groups in intestinal tissue TBARS levels. Tissue SOD, GPx activities and TBARS levels in small intestine were shown in Table II.

\section{Discussion}

It is generally accepted that exercise results in increased ROS production. These ROS generally have a toxic action on tissues. Body cells contain several naturally occurring defence mechanisms to prevent oxidative injury. These protective mechanisms include the enzymes SOD, GPx and catalase. Exercise has effects on antioxidant defence system $(8,13,28)$.

Radak et al. (24) determined a significant increase in the GPx activity of rat kidney on the 1st and 3rd days after an exhaustive exercise in comparison with the control rats. In addition, they obtained that the immunoreactive content of Mn-SOD increased significantly on 1st day after exercise, probably indicating an increase in mitochondrial superoxide formation. However, the immunoreactive $\mathrm{Cu}, \mathrm{Zn}-\mathrm{SOD}$ content of renal tissue was unchanged throughout the experiment. They determined that the exercise induced a significant increase in TBARS concentration on the 3rd day after exercise (24).

In the present study, no significant increase was found in kidney antioxidant enzyme activities and lipid peroxidation after exercise, possibly because exhaustive exercise was not applied.

In various organs, including the small intestine, tissue damage and impaired function develop after temporary ischemia, not only during the hypoxic period, but also after reoxygenation. It was believed that tissue hypoxia played the key role in the pathogenesis of mucosal lesions and it impaired intestinal function after reperfusion (27). Formation of toxic oxygen metabolites has been suggested to play an important role in the development of damage during ischemia/reperfusion injury (11). Malondialdehyde (MDA) is the end product of lipid peroxidation and is a well-known parameter for determining the increased free radical formation in intestinal tissue (25). It was reported that increased lipid peroxidation occurs after reoxygenation of ischemic intestinal tissue $(12,21,22,30,33)$.

The effects of exercise on the antioxidant defence system of the intestinal tissue is not known. In this study, the effects of exercise on oxidative stress in small intestine was investigated. Although exhaustive exercise was not applied, antioxidant defence system in small intestine was affected. Intestinal SOD activity decreased after exercise $(0 \mathrm{~h}$ and 
$3 \mathrm{~h}$ respectively, $\mathrm{p}<0.05, \mathrm{p}<0.01)$ and returned to control levels at $24 \mathrm{~h}$. GPx activity increased after exercise $(0 \mathrm{~h}, \mathrm{p}<0.05)$ and returned to control levels at $3 \mathrm{~h}$. The decrease in SOD activity after exercise could be a result of a decrease of superoxide radicals. Since superoxide radicals inhibit GPx (2), decrease in superoxide radicals may increase in GPx activity. A reason for not having observed lipid peroxidation in intestine in this study, may be due to the low intensity exercise. Therefore submaximal exercise may not cause ischemia in small intestine.

As a conclusion, after a 60-minute exercise with untrained mice, lipid peroxidation was not observed in proximal small intestine and kidney tissues throughout 24 hours. However, the antioxidant defence system in small intestine was affected. These findings could suggest that submaximal exercise may not cause oxidative stress in proximal small intestinal tissue and kidney.

\section{Acknowledgement}

This work was supported by Dokuz Eylül University Research Foundation. Grant no: 0909. 94. 01. 11.

\section{REFERENCES}

1. Bast, A., Haenen, G. R. M. M., Doelman, C. S. A.: Oxidant and antioxidants. Am. J. Med. 91, 2-13 (1994).

2. Blum, J., Fridovich, I.: Inactivation of glutatione peroxidase by superoxide radical. Arch. Biochem. Biophys. 240, 500-508 (1985).

3. Cantwell, J. D.: Gastrointestinal disorders in runners. JAMA 246, 1404-1405 (1981).

4. Carrillo, M. C., Kanai, S., Nokubo, M., Kitani, K.: Deprenyl induces activities of both superoxide dismutase and catalase but not of glutathione peroxidase in the striatum of young male rats. Life Sciences 48, 517-521 (1991).

5. Change, B., Sies, H., Boveris, A.: Hydroperoxide metabolism in mammalian organs. Physiol. Rev. 59, 527-605 (1979).

6. Chatard, J. C., Mujika, I., Guy, C., Lacour, J. R.: Anaemia and iron deficiency in athletes. Practical recommendations for treatment. Sports Med. 27, 229-240 (1999).

7. Clausen, J. P.: Effect of physical training on cardiovascular adjustments to exercise in man. Physiol. Rev. 57, 779-815 (1977).

8. Davies, K. J. A., Quintanilha, A. T., Brooks, G. A., Packer, L.: Free radicals and tissue damage produced by exercise. Biochem. Biophys. Res. Commun. 107, 1198-1205 (1982).

9. Duthie, G. G., Robertson, J. D., Maughaman, R. J., Morrice, C. P.: Blood antioxidant status and erythrocyte lipid peroxidation following distance running. Arch. Biochem. Biophys. 282, 78-83 (1990).

10. Fogoros, R. N.: Runner's trots. Gastrointestinal disturbances in runners. JAMA 243, 1743-1744 (1980).

11. Granger, D. N., Rutili, G., McCord, J. M.: Superoxide radicals in feline intestinal ischemia. Gastroenterology 81, 22-29 (1981). 
12. Günel, E., Çaglayan, F., Çaglayan, O., Dilsiz, A., Duman, S., Aktan, M.: Treatment of intestinal reperfusion injury using antioxidative agents. J. Pediat. Surg. 33, 1536-1539 (1998).

13. Jenkins, R. R.: Free radical chemistry: relationship to exercise. Sports Med., 5, 156-170 (1988).

14. Ji, L. L.: Oxidative stress during exercise: implications of antioxidant nutrients. Free Rad. Biol. Med. 18, 1079-1086 (1994).

15. Jones, G. R., Newhouse, I.: Sport-related hematuria: a review. Clin. J. Sport Med. 7, 199-225 (1997).

16. Korthuis, R. J., Granger, D. N.: Ischemia-reperfusion injury: role of oxygen-derived free radicals. In: Physiology of Oxygen Radicals, edited by Taylor, A. E., Matalon, S., Ward, P. A., Am. Physiol. Soc. 1986, pp. 217-249.

17. Korthuis, R. J., Granger, D. N., Townsley, M. I., Taylor, A. E.: The role of oxygen-derived free radicals in ischemia-induced increases in canini skeletal muscle vasculer permeability. Circ. Res. 57, 599-609 (1985).

18. Markwell, M. A. K., Haas, S. M., Bieber, L. L., Tolbert, N. E.: A modification of the Lowry procedure to simplify protein determination in membrane and lipoprotein samples. Anal. Biochem. 87, 206-210 (1978).

19. McArdle, W. D., Katch, F. I., Katch, V. L.: Exercise Physiology. Fourth Edition, Williams and Wilkins Company, 1996.

20. Michel, H., Larrey, D., Blanc, P.: Hepato-digestive disorders in athletic practice. Presse Med. 23, 479-484 (1994).

21. Nilsson, U. A., Aberg, J., Aneman, A., Lundgren, O.: Feline intestinal ischemia and reperfusion: relation between radical formation and tissue damage. Eur. Surg. Res. 25, 20-29 (1993).

22. Nilsson, U. A., Schoenberg, M. H., Aneman, A., Poch, B., Magadum, S., Beger, H. G., Lundgren, O. Free radical and pathogenesis during ischemia and reperfusion of the cat small intestine. Gastroenterology 106, 629-636 (1994).

23. Paglia, D. E., Valentine, W. N.: Studies on the quantitative and qualitative characterization of erythrocyte glutathione peroxidase. J. Lab. Clin. Med. 70, 158-169 (1967).

24. Radak, Z., Asano, K., Inoue, M., Kizaki, T., Oh-Ishi, S., Suzuki, K., Taniguchi, N., Ohno, H.: Superoxide dismutase derivative prevents oxidative damage in liver and kidney of rats induced by exhaustive exercise. Eur. Appl. Physiol. 72, 189-194 (1996).

25. Rangan, U., Bulkley, G. B.: Prospects for treatment of free radical(mediated tissue injury. Br. Med. Bull. 49, 478-483 (1993).

26. Rehncrona, S., Smith, D. S., Akesson, B., Westerberg, E., Siesjo, B. K.: Peroxidative changes in brain cortical fatty acids and phospholipids, as characterised during $\mathrm{Fe}^{2+}$ and ascorbic acid(stimulated lipid peroxidation in vitro. J. Neurochem. 34, 1630-1638 (1980).

27. Schoenberg, M. H., Beger, H. G.: Reperfusion injury after intestinal ischemia. Crit. Care Med. 21, 1376-1386 (1993).

28. Sen, C. K.: Oxidants and antioxidants in exercise. J. Appl. Physiol. 79, 675-686 (1995).

29. Siegel, A. J., Hennekens, C. H., Solomon, H. S., Van Boeckel, B.: Exercise-related hematuria: findings in a group of marathon runners. JAMA 241, 391-392 (1979).

30. Siems, W., Kowalewski, J., Werner, A., Schimke, I., Gerber, G.: Radical formation in the rat intestine during and following ischemia. Free Radic. Res. Commun. 7, 347-353 (1989).

31. Steward, J. G., Ahlquist, D. A., McGill, D. B., Illstrup, D. M., Schwartz, S., Owen, R. A.: Gastrointestinal blood loss and anemia in runners. Ann. Int. Med. 100, 843-845 (1984).

32. Woods, J. A., Davis, J. M., Mayer, E. P., Ghaffar, A., Pate, R. R.: Effects of exercise on macrophage activation for antitumor cytotoxicity. J. Appl. Physiol. 76, 2177-2185 (1994).

33. Younes, M., Schoenberg, M. H., Jung, H., Fredholm, B. B., Haglund, U., Schildberg, F. W.: Oxidative tissue damage following regional intestinal ischemia and reperfusion in the cat. Res. Exp. Med. 184, 259-264 (1984). 